\title{
Comparison of the Observed Rainfall with Rainfall Estimated by CLIGEN Climate Model in terms of Drought Analysis ${ }^{\#}$
}

\author{
Müberra Erdoğan ${ }^{1, a, *}$, Kadri Yürekli 1,b, Mehmet Murat Cömertt ${ }^{1, c}$ \\ ${ }^{1}$ Department of Biosystem Engineering, Faculty of Agriculture, Gaziosmanpaşa University, 60100 Taşlıçiftlik/Tokat, Turkey
} *Corresponding author

\begin{tabular}{l|l}
\hline A R T I C L E I N F O & A B S T R A C T \\
$\begin{array}{l}\text { "This study was presented as an oral } \\
\text { presentation at the 4th International } \\
\text { Anatolian Agriculture, Food, } \\
\begin{array}{l}\text { Environment and Biology Congress } \\
\text { (Afyonkarahisar, TARGID 2019) }\end{array}\end{array}$ & $\begin{array}{l}\text { Standardized Precipitation Index (SPI) is used to determine dry and humid periods according to the } \\
\text { cumulative probability method at different time scales. . In this study, the rainfall data between the } \\
\text { years of 1980-2018 belonging to of Kayseri Meteorology Station was simulated by CLIGEN } \\
\text { stochastic climatic data generator. SPI indices calculated by using observed and simulated } \\
\text { precipitation were evaluated with the statistical methods at the time scales of 3-, 6-, 9- and 12- } \\
\text { months. The SPI values of 3-, 6-, 9- and 12- month which are observed and simulated with CLIGEN } \\
\text { are close to each other and the performance of the model is very high in calculating the SPI values } \\
\text { of these time series. However, as the time period increased, the model's representative ability } \\
\text { decreased. }\end{array}$ \\
Research Article &
\end{tabular}

Accepted : 06/11/2019

Keywords:

CLIGEN

Standardized Precipitation Index

Drought

Rainfall

Kayseri

Türk Tarım - Gıda Bilim ve Teknoloji Dergisi 7(sp1): 6-12, 2019

\section{CLIGEN İklim Modeli ile Tahmin Edilen Yağmur ile Gözlenen Yağmurun Kuraklık Analizi Açısından Karşılaştırılması}

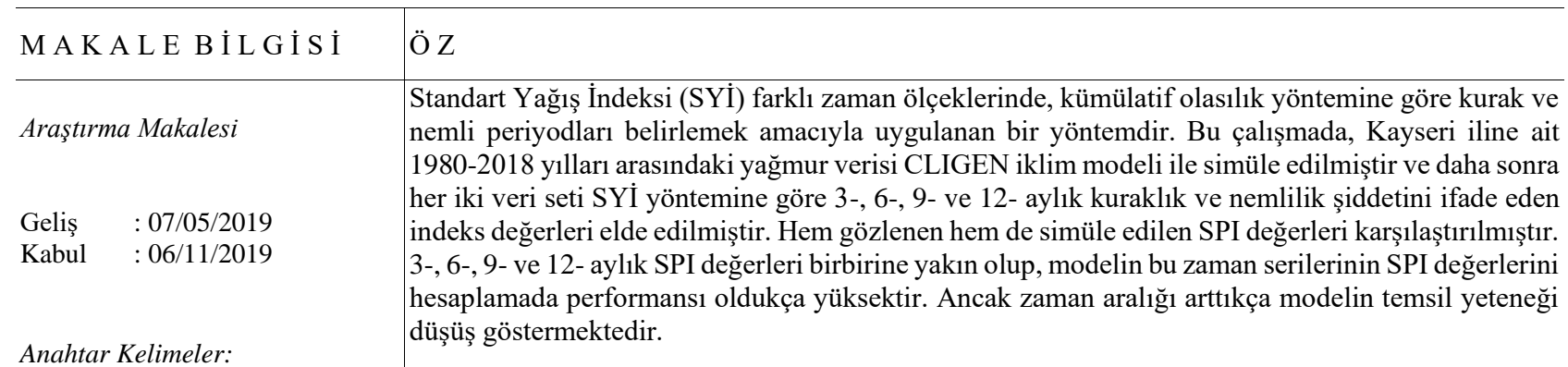

\section{CLIGEN}

Standartlaştırılmış Yağış İndeksi

Kuraklık

Yağmur

Kayseri

Standart Yağış İndeksi (SYİ) farklı zaman ölçeklerinde, kümülatif olasılık yöntemine göre kurak ve 1980-2018 yılları arasındaki yağmur verisi CLIGEN iklim modeli ile simüle edilmiştir ve daha sonra her iki veri seti SYİ yöntemine göre 3-, 6-, 9- ve 12- aylık kuraklık ve nemlilik şiddetini ifade eden 3-, 6-,9-ve 12-aylk SPI ḑ̌ hesaplamada performansı oldukça yüksektir. Ancak zaman aralığ arttıkça modelin temsil yeteneği düşüş göstermektedir. 


\section{Introduction}

Natural disasters have an important place in human life from past to present. One of the most important natural disasters is drought. Drought has the greatest impact on life and economy compared to other natural disasters and, it has the property of development under different meteorological and environmental conditions. Drought occurs when rain falls below average rainfall. Because of this water shortage, vital activities are negatively affected. In the literature, there is types of drought categorized with regard to its impacts on sectors (Oğuztürk ve Y1ld1z, 2014). Shah et al. (2015), were divided into three drought classes in their study. These classes are named as meteorological, hydrological and agricultural drought. Meteorological drought is associated with a long drought period with no rain and snow. Therefore, its definition depends on comparison of the rainfall that occurs in a particular area and year against the average rainfall for many years. Hydrologic drought is related to lack of water amount in streams, reservoirs and lakes resulting from low rainfalls and, hydrological drought occurs when the meteorological drought is prolonged. Agricultural drought is closely related to the various characteristics of meteorological drought. It is defined as the lack of water to meet the need of the plant at soil (Kapluhan, 2013).

Turkey is located in semi-arid - semi-humid middle latitude region. While cyclically in some periods are dominate more dry climatic conditions, in some period is dominated more humid climatic conditions. There have been various drought periods throughout human history. The location of Turkey is a semi-arid climate area of the World and, has faced many drought periods in the past (Turan, 2018). The most severe of drought events in Turkey occurred in 1953-1954, 1956, 1964, 1973, 1977, 1984, 1989-1991, 1999-2000, 2001-2004 ve 2007-2008 years (Türkeş ve Tatlı, 2009; Oğuztürk ve Yıldız, 2014).

The possible effect of drought begins to show itself after a long time. It is therefore difficult to monitor its formation. Many climate studies in the literature, have estimated droughts by using statistical methods in context of its frequency, duration, intensity and the areas influence of drought. These methods are the Palmer Drought Severity Index (PDSI) (Palmer, 1965), Decile Index (DI) (Gibbs and Maher, 1967), China-Z Index (CZI) (Wu et al., 2001), Surface Water Supply Index (SWSI) (Shafer and Dezman, 1982) and Standardized Precipitation Index (SPI) (McKeeet al., 1993) Modified Standardized Precipitation Index (Türkeş ve Tatlı, 2009).

The main purpose of this study is to simulate the rainfall data belonging to Kayseri province located in the Central Anatolia with CLIGEN stocastic climatic data generator and, to compare the SPI obtained from the simulated rainfall to SPI calculated from observed data. To reach this targed mentioned, the SPI values were calculated for 3-, 6- ,9- and 12- time scales.

\section{Material and Method}

Geographical location of Kayseri Province in Turkey selected as the study area is in Figure 1. Kayseri is situated between $37^{\circ} 45^{\prime}-38^{\circ} 18^{\prime}$ north latitudes and $34^{\circ} 56^{\prime}-36^{\circ} 58^{\prime}$ east longitudes. The elevation (mls) is $1053 \mathrm{~m}$. Kayseri, which is located in Central Anatolia Region, has a continental climate. Summers are hot and dry; winters are cold and snowy. However, the climate of this province varies depending on the height. In summer, the average temperature is $21.4^{\circ} \mathrm{C}$. In winter, temperature change between $-1.2{ }^{\circ} \mathrm{C}$ and $-6.2^{\circ} \mathrm{C}$. The average annual rainfall is $399,6 \mathrm{~mm}$. In the study area, occurs the most rainfall in March, April and May, the least precipitation in July, August and September (Meteorological Service, 2019).

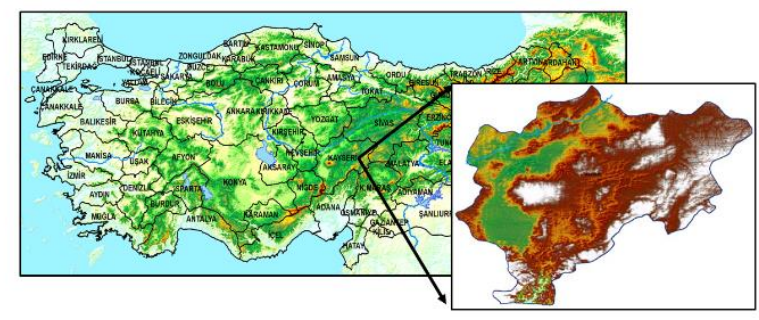

Figure 1 Geographical position to Turkey of Kayseri Province

\section{Method}

In the study, CLIGEN stochastic climatic data generator were used for the simulation of rainfall between 1980-2018 (39 years) for Kayseri. Drought analysis of the observed and simulated data were done by standardized precipitation index method (SPI).

\section{CLIGEN Climate Model}

CLIGEN introduced by Nicks et al. (1995) is a climate model developed by using meteorological data from the centre and south of America. In the simulation of rainfall with CLIGEN, 7 parameters are used, namely daily rainfall, maximum and minimum temperature, dew point, solar radiation, wind speed and direction. Markov chain method is used to predict daily rainfall. In the methodology, the probability of consecutive rainy days and the probability of dry day coming after the rainy day are characterized by the symbols called, P(W/W) and P(W/D), respectively. Normal distribution is used to determine daily rainfall. The probability of precipitation is calculated using the equation given below.

$$
P(W)=\frac{P(W / D)}{1-P(W / W)+P(W / D)}
$$

If a random number, which is deduced from a uniform distribution for each day, is less than the precipitation probability for the certain day case, precipitation occurs. In the constitute wet days, a skewed normal distribution is used to constitute the daily precipitation quantitys (Nick and Lane, 1989; Al-Mukhtar et al., 2014).

$$
\mathrm{x}=\left[\left(\frac{\mathrm{g}}{2}\left(\frac{\mathrm{R}-\mathrm{u}}{\mathrm{s}}\right)+1\right)^{1 / 3}-1\right]+\frac{\mathrm{g}}{6}
$$

Where $\mathrm{x}=$ standard normal random variable; $\mathrm{R}=$ daily precipitation amount; $\mathrm{u}, \mathrm{s}, \mathrm{g}=$ mean, standard deviation and skew coefficient of daily precipitation amount.

During the development of the model, many academicians have made an effort in the analysis of the 
parameters used in the model and in changing the incorrect parameters. For example, Nearing et al. (2005) examined errors in the simulation of daily rainfall data. ( $\mathrm{Yu}, 2005)$ developed a simulation method of calculating rainfall intensity. Demir et al. (2018) evaluated rainfall parameters from CLIGEN climate model for long years in Tokat province. According to the results of the study, it is seen that the model is quite successful in estimating annual and monthly average values but found that the average of seasons were smaller than the observed value.

\section{Standardized Precipitation Index}

Standardized Precipitation Index (SPI) method was developed by Mckee et al. (1993). The advantage of the methodology is input data which is only the rainfall. The most important advantage of this methodology is to use different time scales in detecting the drought effect based on precipitation on the deficit in underground and surface water resources. Determining the drought classes (Table 1) and probabilities of SPI values calculated from the rainfall data at a given station, important information can be provided for struggle plans with drought.

At least 30 years of rainfall records are used in this method. Daily rainfall depths are summed mathematically to form monthly rainfall series. In its most general form, SPI is calculated by the equation given below;

$$
\mathrm{SPI}=\frac{\mathrm{X}_{\mathrm{i}} \overline{\mathrm{X}}_{\mathrm{i}}}{\sigma}
$$

In this equation, $X_{i}$ monthly rainfall data; $\bar{X}_{i}$ is average of rainfall data set and $\sigma$ is standard deviation of rainfall. But, if the rainfall data is not normally distributed, the data should be transformed staistically. SPI method is disclosed in the literatures in detail (McKee et al., 1993; Guttman, 1999; Giddings et al., 2005; Wu et al., 2005; Kumar et al., 2009; Belayneh and Adamowski, 2012; Yetmen, 2013; Shah et al., 2015).

Table 1. Drought and Wet Classification by SPI Drought Index (McKee et.al, 1993)

\begin{tabular}{l|l}
\hline \multicolumn{1}{c|}{ SPI Values } & \multicolumn{1}{c}{ Classification } \\
\hline Greater than 2.0 & Extraordinary Damp \\
1.5 to 1.99 & Extreme Damp \\
1 to 1.49 & Severe Damp \\
0.5 to 0.99 & Medium Damp \\
0.0 to 0.49 & Light Damp \\
0.0 to $(-0.49)$ & Light Arid \\
$(-0.5)$ to $(-0.99)$ & Medium Arid \\
$(-1.0)$ to $(-1.49)$ & Severe Arid \\
$(-1.50)$ to $(-1.99)$ & Extreme Arid \\
Less than $(-2.0)$ & Extraordinary Arid \\
\hline
\end{tabular}

\section{Results and Discussion}

The rainfall data from Kayseri Province for the years from 1980 to 2018 was simulated by CLIGEN stochastic climatic data generator. The SPI values at 3-, 6-, 9- and 12time scales of both observed and simulated rainfall were evaluated in terms of drought. The annual average of the observed and simulated rainfall amounts is $397.8 \mathrm{~mm}$ and $346.6 \mathrm{~mm}$, respectively. The highest rainfall among the observed annual rainfalls was $600.5 \mathrm{~mm}$ in 1989 and, the lowest rainfall was $275.7 \mathrm{~mm}$ in 1988 . The model predicted the annual highest rainfall as $501 \mathrm{~mm}$ in 1987 and the lowest rainfall as 230,6 $\mathrm{mm}$ in 1988 (Graphic 1, 2 and Table 2). The predicted rainfall heights were lower than the observed rainfalls. This reason for this is probably Cligen methodology. Kayseri is commonly experienced extreme rainfall events especially in spring season. Due to the Cligen stochastic climatic data generator model algorithm, it creates a continuous water budget. Since the continuous precipitation affects the budget negatively, it predicts precipitation below the observed value.

\section{The Results of Drought Analysis}

In the study, for the time scales of 3-, 6-, 9- and 12months, visual graphics of standardized precipitation index (SPI) values are given in Graphic 3, 4, 5, 6, 7, 8, 9, 10. As can be seen from the SPI values of 3 months, it was detected that 292 months were wet at different levels and 174 months were dry at different levels. Extreme dry and extreme wet events were not observed. Based on annual SPI values, 25 and 14 years were found to be humid and dry at different levels, respectively. The 1989 and 2001 years were maximum wet and dry (Graphic 3 ) respectively. According to the SPI results of 3 months time scale based on CLIGEN, 325 and 141 months were determined as wet and dry at different levels, respectively. Extremely dry and wet events were not observed. Additionally, the annual SPI values showed wet in 33 years and drought in 6 years at different levels. There was maximum wet in 1989 year and severe drought in 2001 year (Graphic 4).

With respect to the SPI values of the 6 months, it was determined that 245 months were wet at different levels and 118 months were dry at different levels. While 11 drought events were observed in extreme conditions, 8 extreme wet events were observed. When looking over SPI data sets from annual rainfall amounts, 20 years and 19 years were found to be wet and dry according to classification given in the Table 1, respectively. Maximum wet in 1989 and, the maximum dry in 2001 were detected (Graphic 5). The SPI values of 6-month from CLIGEN had wet in 220 months and dryness in 243 months at different levels. Excessively dry 11 events were observed while excessive wet 3 events were observed. The annual SPI values were found to be wet in 20 years and dry in 19 years at different levels. There were maximum wet in 2015 and the drought in 2001 (Graphic 6).

According to the SPI values of 9-month, it was determined that 230 months were wet at different levels and 230 months were dry at different levels. Excessively dry 11 events were detected while excessive wet 13 events were observed. The annual SPI values were found to be wet in 18 years and dry in 21 years at different levels. Maximum wet in 2015 and maximum dry in 2001 (Graphic 7). With respect to the SPI values of the 9-month, it has been determined that 243 months are wet at different levels and 217 months are dry at different levels. Excessively dry 14 events were observed while excessive wet 9 events were observed. The annual SPI values were found to be humid in 18 year and dry in 21 years at different levels. It was seen maximum wet in 2015 and the drought in 2001 (Graphic 8). 
Table 2 Observed and predicted annual rainfall amount of Kayseri

\begin{tabular}{l|ccccc}
\hline Years & Observed rainfall & CLIGEN rainfall & Years & Observed rainfall & CLIGEN rainfall \\
\hline 1980 & 409.5 & 387.9 & 2000 & 298.3 & 249.4 \\
1981 & 396.3 & 290.1 & 2001 & 294.7 & 266.5 \\
1982 & 317.2 & 253.1 & 2002 & 417.9 & 376.0 \\
1983 & 403.7 & 371.7 & 2003 & 313.7 & 288.7 \\
1984 & 275.7 & 237.6 & 2004 & 337.0 & 328.6 \\
1985 & 357 & 351.0 & 2005 & 324.1 & 326.1 \\
1986 & 426.6 & 392.0 & 2006 & 449.3 & 299.1 \\
1987 & 531.3 & 501.2 & 2007 & 424.2 & 333.2 \\
1988 & 281.2 & 230.6 & 2008 & 292.4 & 268.6 \\
1989 & 600.5 & 467.9 & 2009 & 564.8 & 468.9 \\
1990 & 452.6 & 376.9 & 2010 & 437.0 & 359.5 \\
1991 & 491.3 & 432.7 & 2011 & 406.4 & 412.8 \\
1992 & 403.4 & 371.0 & 2012 & 407.0 & 395.3 \\
1993 & 360 & 313.1 & 2013 & 303.7 & 250.4 \\
1994 & 279.5 & 276.0 & 2014 & 507.8 & 396.1 \\
1995 & 387.7 & 286.7 & 2015 & 511.5 & 454.9 \\
1996 & 400.3 & 377.1 & 2016 & 363.8 & 285.5 \\
1997 & 415.7 & 362.6 & 2017 & 350.2 & 343.5 \\
1998 & 504.8 & 455.5 & 2018 & 366.3 & 313.1 \\
1999 & 449 & 366.9 & & & \\
\hline
\end{tabular}

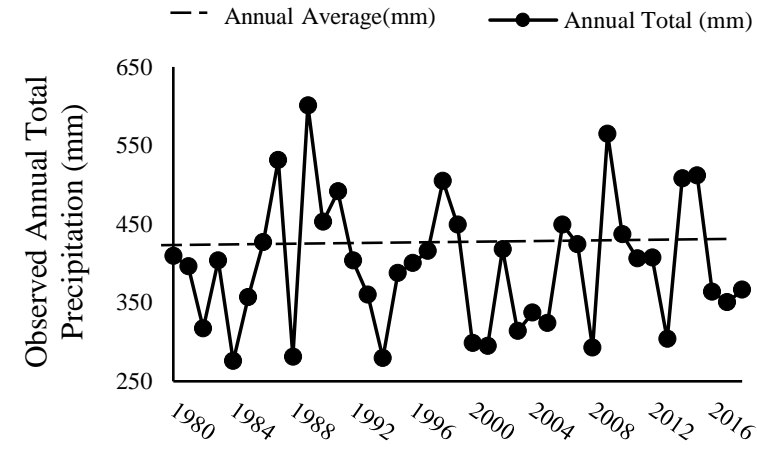

Graphic 1 Kayseri Observed Rainfall Series

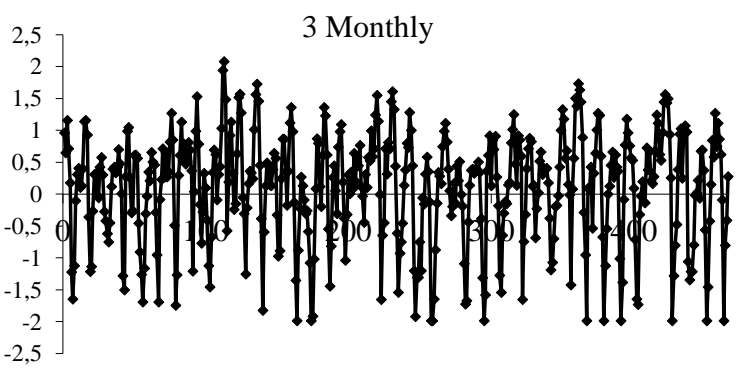

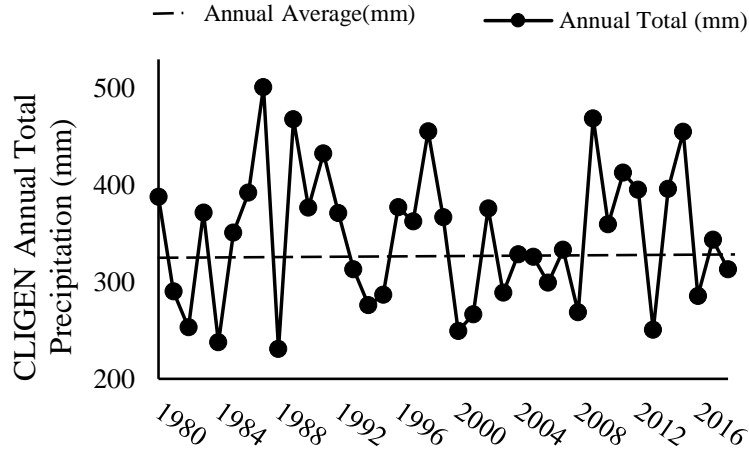

Graphic 2 Kayseri CLIGEN Rainfall Series

Graphic 3 Three Monthly and Annual SPI data of Observed Rainfall belong to Kayseri
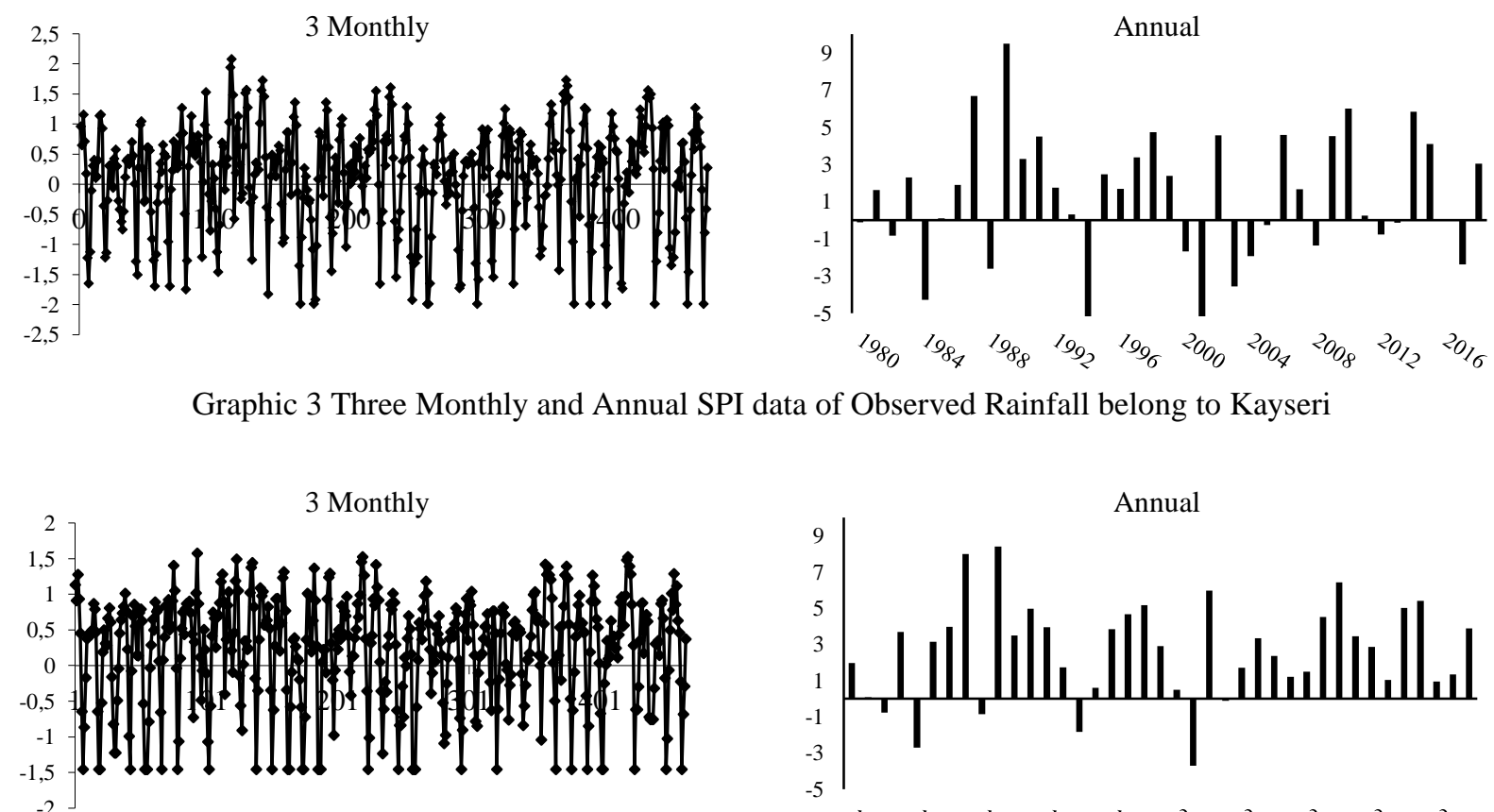

Graphic 4 Three monthly and Annual SPI data of CLIGEN Rainfall belong to Kayseri 

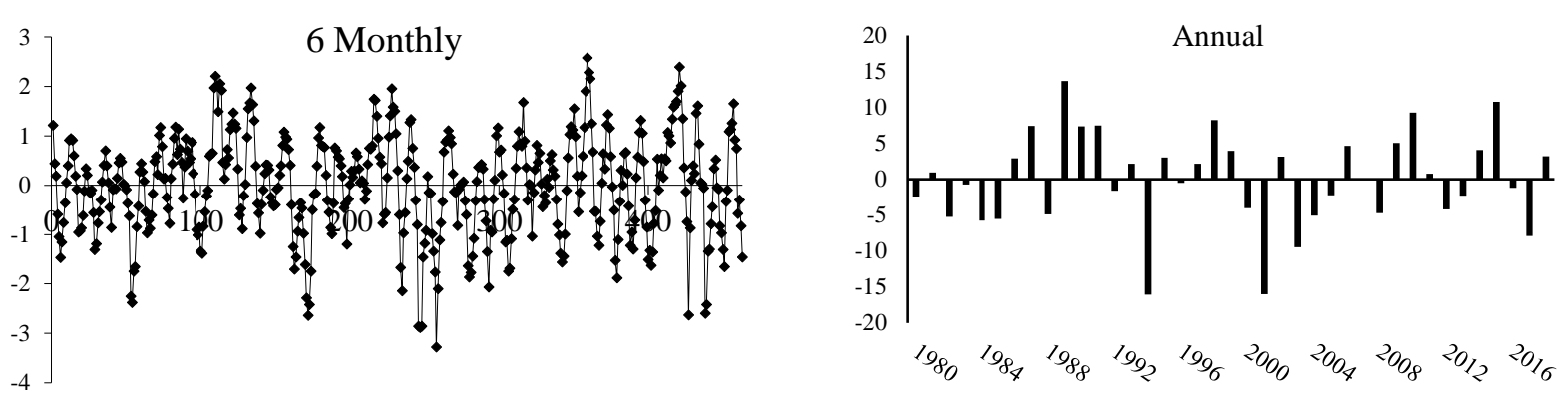

Graphic 5 Six Monthly and Annual SPI data of Observed Rainfall belong to Kayseri
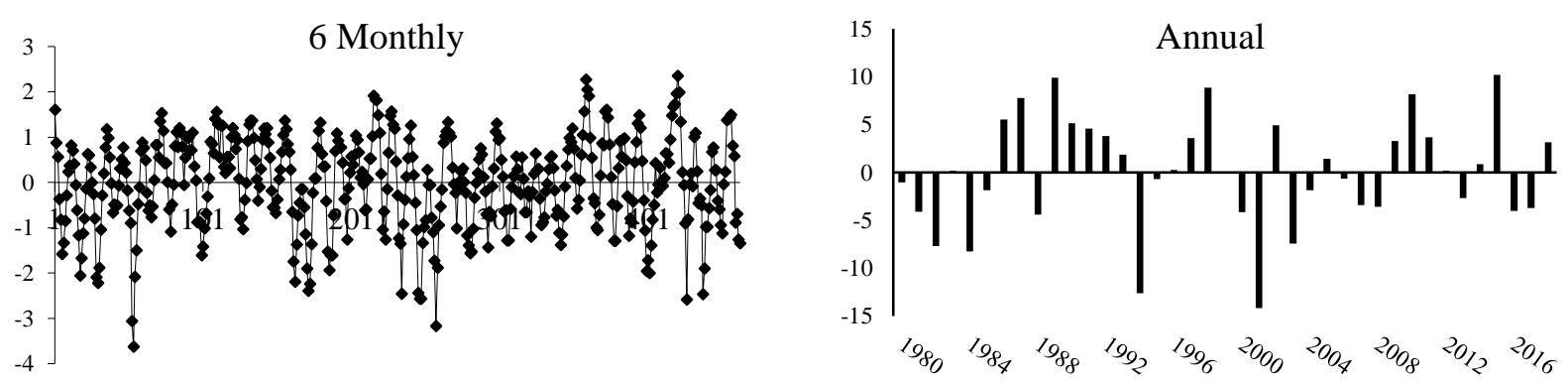

Graphic 6 Six Monthly and Annual SPI data of CLIGEN Rainfall belong to Kayseri
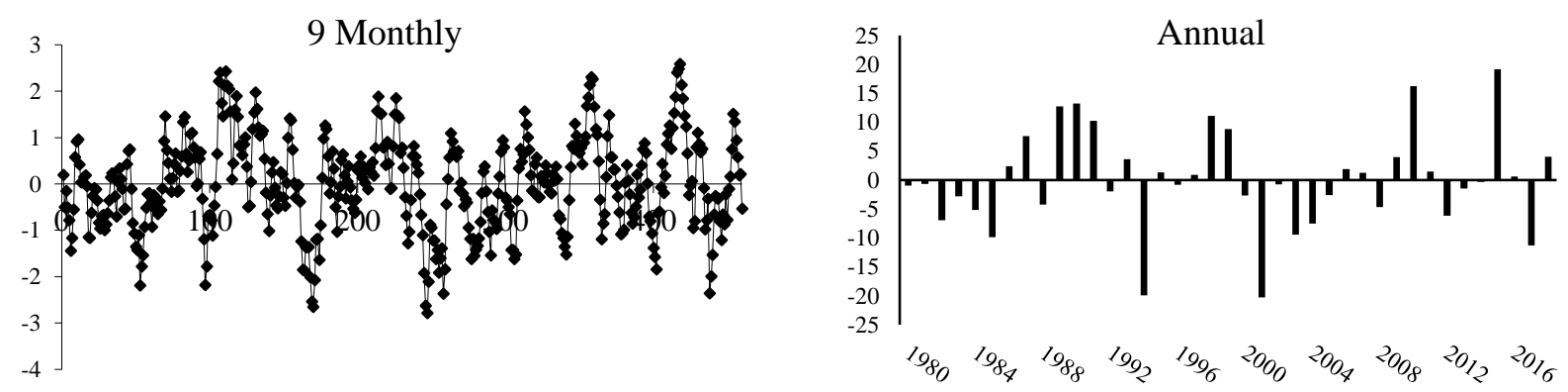

Graphic 7 Nine Monthly and Annual SPI data of Observed Rainfall belong to Kayseri
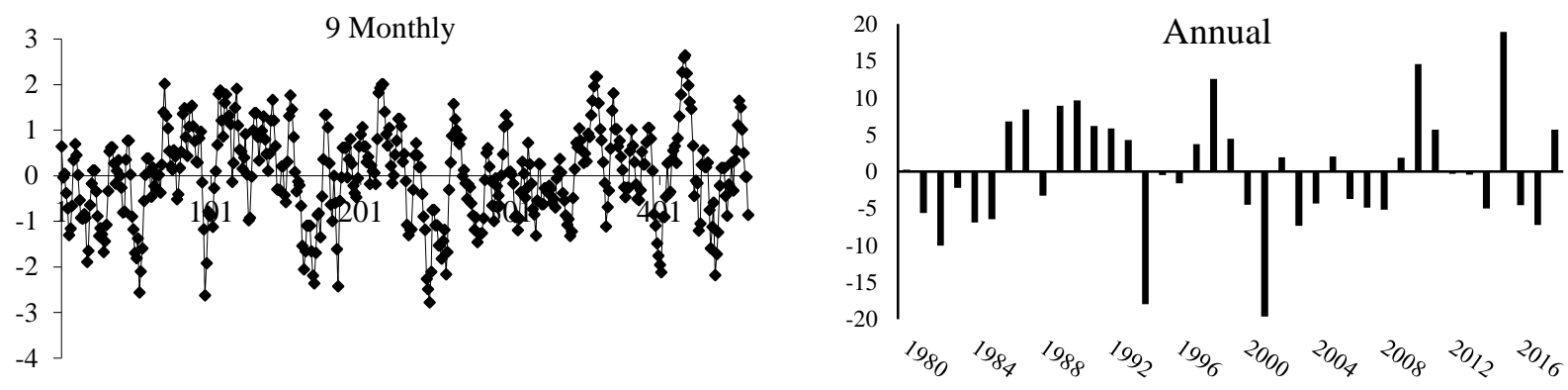

Graphic 8 Nine Monthly and Annual SPI data of CLIGEN Rainfall belong to Kayseri
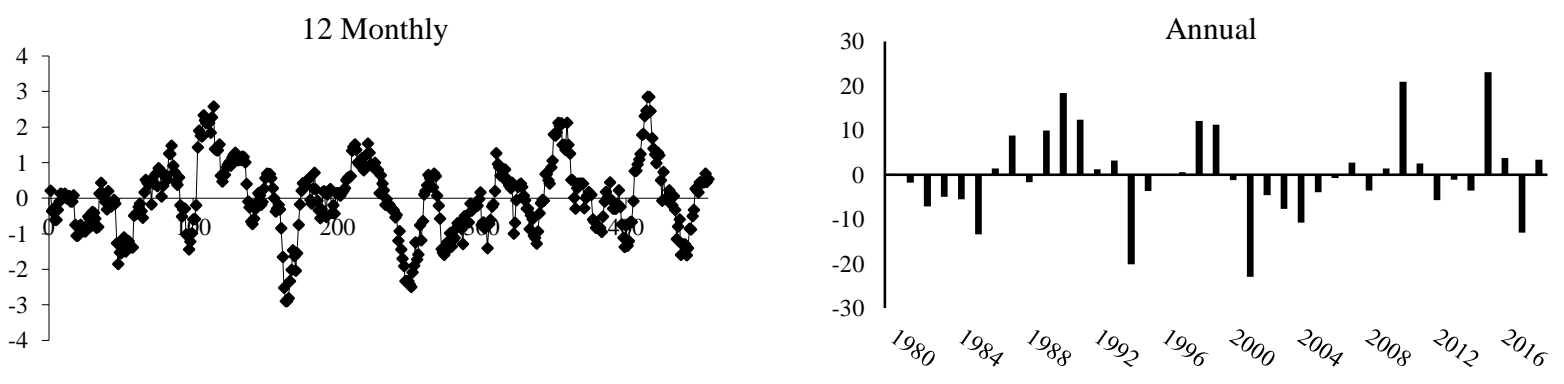

Graphic 9 Twelve Monthly and Annual SPI data of Observed Rainfall belong to Kayseri 

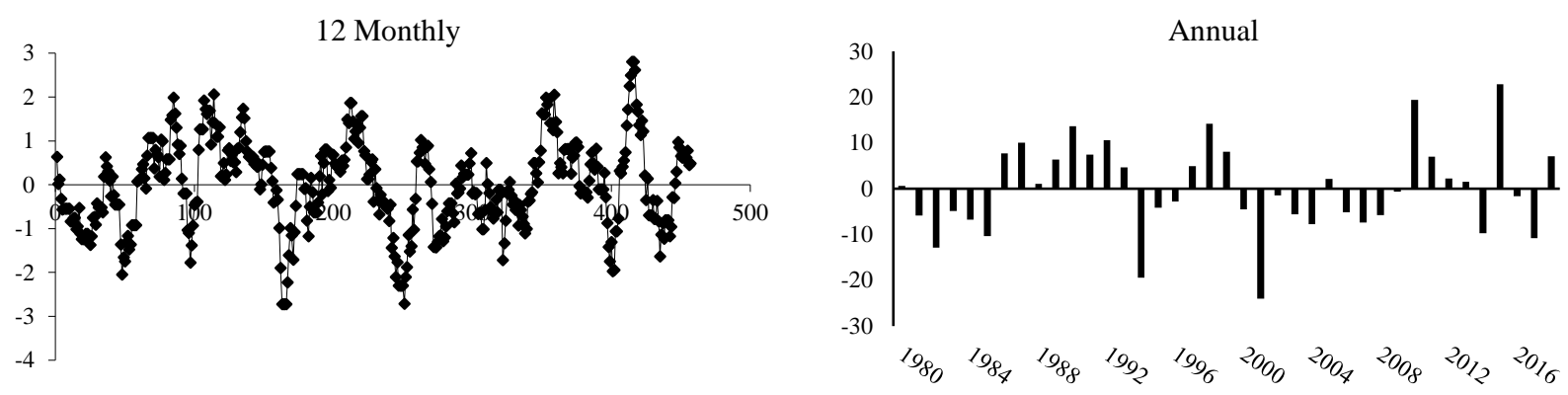

Graphic 10 Twelve Monthly and Annual SPI data of CLIGEN Rainfall belong to Kayseri
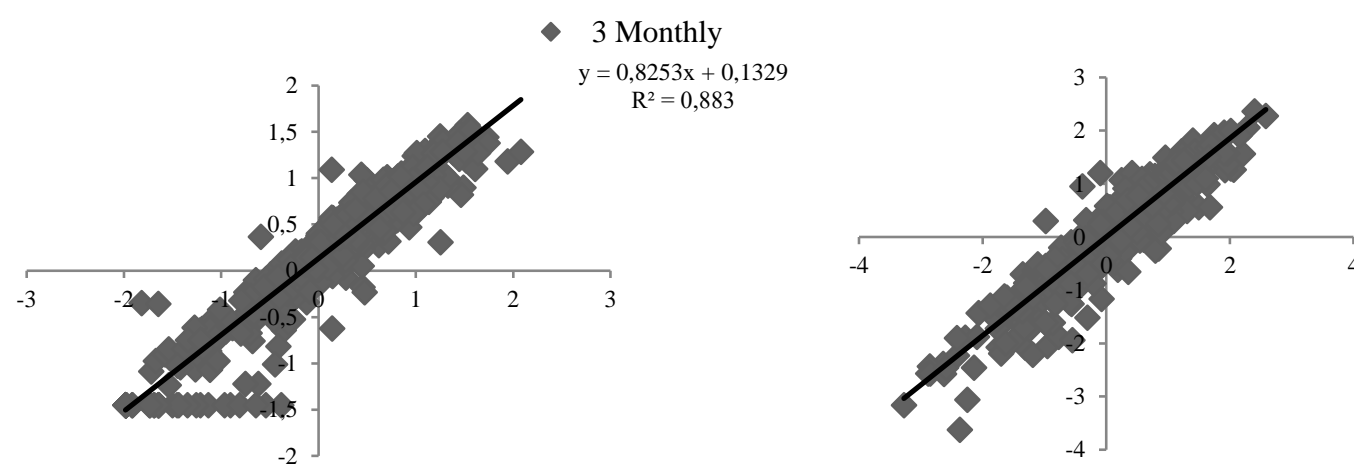
-6 Monthly $\mathrm{y}=0,9277 \mathrm{x}+0,0011$ $\mathrm{R}^{2}=0,8603$
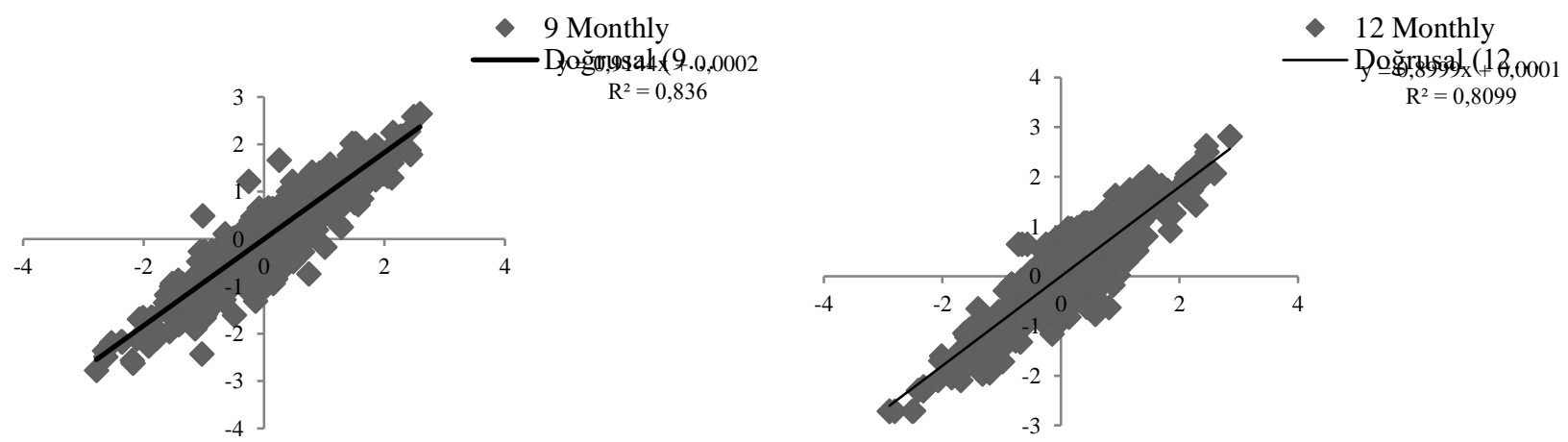

Graphic 11 Relationship between observed and simulated SPI values in Kayseri

When the SPI values of 12-month were examined. it was determined that 229 months were wet at different levels and. 228 months were dry at different levels. Excessively dry 13 events were observed while excessive humid 16 events were observed. The annual SPI values were found to be wet in 18 years and dry in 21 years at different levels. It was seen maximum wet in 2015 and the maximum dry in 2001 (Graphic 9). When the SPI value of the 12-month from CLIGEN is examined. it has been determined that 233 months were wet at different levels and 224 months were dry at different levels. Excessively dry 13 events were observed while excessive wet 7 events were observed. The annual SPI values were found to be wet in 19 years and dry in 20 years at different levels. It was seen maximum wet in 2015 and the dry in 2001 (Graphic 10).

The relationship between the observed and simulated SPI values of 3-. 6-. 9- and 12- month is given in Graphic 11. For all-time series. $\mathrm{R}^{2}$ values was found to be 0.88 $0.86-0.83-0.80$. respectively. The SPI values of 3-. 6-. 9and 12- month which are observed and simulated with CLIGEN are close to each other and the performance of the model is very high in calculating the SPI values of these time series. However. as the time period length increased. the model's representative ability decreased.

\section{Conclusion}

In this study. drought analysis based on SPI was performed for various time scales (3-. 6-. 9- and 12- month) in Kayseri Provinces. SPI method was applied to 39 years and the drought characteristics of these values in different time periods were examined. It was observed that the values found according to the SPI analyses represent the climatic conditions of the region. The drought values simulated with CLIGEN were quite similar to the observed data. These show that the performance of the model is quite high in Kayseri climate conditions. As a result stochastic data needs of drought studies can be meet by the CLIGEN data generator for the Kayseri.

\section{References}

Al-Mukhtar M. Dunger V. Merkel B. 2014. Evaluation of the climate generator model CLIGEN for rainfall data simulation in Bautzen catchment area. Germany. Hydrology Research. 45(4-5): 615-630.

Belayneh A. Adamowski J. 2012. Standard Precipitation Index Drought Forecasting Using Neural Networks. Wavelet Neural Networks. and Support Vector Regression. Standard Precipitation Index Drought Forecasting Using Neural Networks. Wavelet Neural Networks. and Support Vector Regression. doi:10.1155/2012/794061. 
Demir S. Oğuz İ. Ciba ÖF. 2018. Long Years Precipitation Parameters by CLIGEN Precipitation Model in Tokat Province. Iğdır University Journal of the Institute of Science and Technology. 8(1): 319-328.

Gibbs WJ. Maher JV. 1967. Rainfall Deciles as Drought Indicators.Commonwealth of Australia: Melbourne. Bureau of Meteorology Bulletin No. 48.

Giddings L. Soto M. Rutherford BM. Maarouf A. 2005 Standardized Precipitation Indekx Zones for Mexico. Atmosfera. 33-56.

Guttman NB. (1999). Accepting the Standardized Precipitation Index: A calculation algorithm. Journal of the American Water Resources Association. 35: 311-322.

Kapluhan E. 2013. Drought and Drought in Turkey Effect of Agriculture. Marmara Coğrafya Dergisi. 27: 487-510.

Kumar MN. Murthy CS. Sesha Saib MVR. Royb PS. 2009. On the use of Standardized Precipitation Index (SPI) for drought intensity assessment. Meteorol. Appl. 16: 381-389.

McKee TB. Doesken NJ. Kleist J. 1993. The Relationship of Drought Frequency and Duration of time Scales. Presented at the Eighth Conference on Applied Climatology. American MeteorologicalSociety: Anaheim. CA; $179-186$.

Meteorological Service. 2019. https://www.mgm.gov.tr /veridegerlendirme/il-ve-ilceler-istatistik.aspx?k=H. (22.09.2019).

Nearing MA. Jetten V. Baffaut C. Cerdan O. Couturier A. Hernandez M. Le Bissonnais Y. Nichols MH. Nunes JP. Renschler CS. 2005. Modeling response of soil erosion and runoff to changes in precipitation and cover. Catena 61. 131-154.

Nicks AD. Lane LJ. Gander GA. 1995. CLIGEN weather generator. In: Flanagan. D.C. Nearing. M.A. (Eds.). USDA-Water Erosion Prediction Project: HillslopeProfile and Watershed Model Documentation. USDA-ARS National Soil Erosion Research Laboratory. West Lafayet. pp. 2.1-2.22.

Nicks AD. Lane LJ. 1989. Weather Generator. Chapter 2. In: USDA-Water Erosion Prediction Project: Hillslope Profile Version. NSERL Report No. 2 (L. J. Lane \& M. A. Nearing. eds). USDA-ARS National Soil Erosion Research Laboratory. West Lafayette. Indiana. pp. 2.1-2.22.
Oğuztürk G. Y1ldız O. 2014. Drought Analysis for Different Time Periods the City of Kirıkkale. International Journal of Engineering Research and Development. 6(2).

Palmer WC. 1965. Meteorological drought. Weather Bureau ResearchPaper No. 45. U.S. Department of Commerce: Washington. D.C.

Shafer BA. Dezman LE. 1982. Development of a Surface Water Supply Index (SWSI) to Assess the Severity of Drought Conditions in Snowpack Runoff Areas. Proceedings of the Western Snow Conference. Colorado State University: Fort Collins. CO; $164-175$.

Shah R. Bharadiya N. Manekar. V. 2015. Drought Index Computation Using Standardized Precpitation Index (SPI) Method for Surat District. Gujarat. Aqutic Procedia. 4: 12431249.

Turan ES. 2018. Türkiye'nin İklim Değişikliğine Bağlı Kuraklık Durumu. Journal of Natural Hazards and Environment. 4(1): 63-69.

Türkeş M. Tatlı. H. 2009. Use of the Standardized Precipitation Index (SPI) and a Modified SPI for Shaping the Drought Probabilities over Turkey. International Journal of Climatology. 29: 2270 - 2282.

Wu H. Hayes MJ. Welss A. Hu Q. 2001. An Evaluation the Standardized Precipitation Index. the China-Z Index and the Statistical Z-score. International Journal of Climatology. 21: $745-758$.

Wu H. Hayes MJ. Wilhite DA. Svoboda MD. (2005) The effect of the length of record on the standardized precipitation index calculation. Int J Climatol 25: 505-520.

Yetmen H. 2013. Van Lake Basin Drought Analysis. 21. Yüzy1lda Eğitim ve Toplum. 3(5): 184-198.

$\mathrm{Yu}$ B. 2005. Adjustment of CLIGEN Parameters to Generate Precipitation. Change Scenarios in Southeastern Australia. Catena 61. 196-209. 